\title{
EVALUASI PENERAPAN SISTEM KESELAMATAN KEBAKARAN PADA BANGUNAN GEDUNG RUMAH SAKIT DR. M. DJAMIL PADANG
}

\author{
Yervi Hesna ${ }^{1}$, Benny Hidayat ${ }^{2}$, Satria Suwanda ${ }^{2}$
}

\begin{abstract}
ABSTRAK
Fenomena dalam keselamatan kebakaran gedung di Indonesia memperlihatkan bahwa pihak pemilik atau pengelola gedung lebih bergantung kapada Dinas Pemadam Kebakaran. Padahal proses membesarnya kebakaran sangat cepat sehingga pemadaman harus dilakukan secara cepat selagi kebakaran masih kecil. Dan hal ini lebih mungkin dilakukan oleh pihak pemilik/ pengelola gedung atau pengguna gedung tersebut dari pada harus menunggu PMK. Oleh karena itu penggunaan sebuah tool diharapkan dapat dijadikan sebagai acuan persyaratan teknis yang diperlukan dalam perencanaan, pelaksanaan dan pemanfatan oleh penyedia jasa dan pemilik/ pengelola bangunan gedung, serta pengendalian penyelenggaraan bangunan gedung, melalui mekanisme perijinan, pemeriksaan dan enertiban oleh pemerintah untuk mewujudkan bangunan gedung yang aman terhadap bahaya kebakaran.

Percobaan ini dilakukan dengan cara mengaplikasikan sebuah tool pemeriksaan keandalan bangunan terhadap bahaya kebakaran pada gedung-gedung yang terletak di komplek RSUP DR. M. Djamil Padang berdasarkan komponen sistem keselamatan bangunan (KSKB), yang terdiri dari kelengkapan tapak, sarana penyelamatan, sistem proteksi aktif dan sistem proteksi pasif. Pemeriksaan ini bertujuan untuk mengetahui tingkat keandalan bangunan gedung berupa Nilai Keandalan Sistem Keselamatan Bangunan (NKSKB) yang merupakan persentase total dari penjumlahan persentase komponen sistem keselamatan bangunan (KSKB). Dari survei yang dilakukan terhadap 27 bangunan, 25 diantaranya memiliki tingkat keandalan bangunan yang baik sedangkan 2 bangunan lainnya memiliki tingkat keandalan bangunan yang cukup.
\end{abstract}

Kata Kunci : sistem keselamatan kebakaran, bangunan gedung.

\section{LATAR BELAKANG}

Perkembangan struktur bangunan yang semakin kompleks dan penggunaan bangunan yang semakin beragam serta tuntutan keselamatan yang semakin tinggi, membuat pihak pemilik atau pengembang bangunan harus mulai memikirkan Fire Safety Management. Beberapa kejadian kebakaran pada bangunan tinggi baik bangunan komersil maupun perkantoran mestinya menjadi pelajaran penting dalam penyiapan Fire Safety Management.

Pada saat terjadi kebakaran, ada empat hal yang perlu diperhatikan berkaitan dengan bahaya api, yaitu penghuni bangunan (manusia), isi bangunan (harta), struktur bangunan dan bangunan yang letaknya bersebelahan. Tiga hal yang pertama berkaitan dengan bahaya api yang ada pada bangunan yang terbakar, sedangkan hal yang terakhir merupakan pertimbangan bagi bangunan lainnya dan lingkungan komunitas secara menyeluruh.

\footnotetext{
${ }^{1}$ Staf Pengajar Jurusan Teknik Sipil Fakultas Teknik Universitas Andalas, e-mail: yervi@ft.unand.ac.id

${ }^{2}$ Staf Pengajar Jurusan Teknik Sipil Fakultas Teknik Universitas Andalas, e-mail: bennyhidayat@ft.unand.ac.id

${ }^{3}$ Mahasiswa Jurusan Teknik Sipil Fakultas Teknik Universitas Andalas
} 
Berdasarkan data dari Bidang Pemadam Kebakaran Dinas Kessos, PB2 Kota Padang, terdapat peningkatan frekuensi kebakaran yang cukup signifikan di Kota Padang sejak Tahun 2006. Sepanjang tahun 2006 frekuensi kejadian kebakaran di Kota Padang sebanyak 62 kali, kemudian pada tahun 2007 frekuensi kejadian kebakaran meningkat menjadi 94 kali, sedangkan untuk tahun 2008 sejak bulan Januari 2008 sampai bulan September 2008 sudah tercatat sebanyak 94 kali kejadian kebakaran di Kota Padang. Walaupun kejadian kebakaran mayoritas terjadi pada rumah penduduk, namun $60 \%$ penyebabnya adalah arus pendek listrik.

Hasil identifikasi bahaya kebakaran di bangunan rumah sakit didapatkan fakta terdapat empat sumber utama penyebab kebakaran, yakni penggunaan peralatan listrik, sambungan pendek arus listrik, menggunakan tabung gas bertekanan, menggunakan berbagai macam bahan kimia baik cair maupun padat yang bersifat flammable, korosif dan harmful. Sehingga dapat disimpulkan rumah sakit termasuk kategori bangunan yang beresiko kebakaran dilihat dari banyaknya sumber potensi bahaya dan penghuninya sebagian adalah orang sakit yang tidak mampu melayani dan menyelamatkan dirinya sendiri apabila terjadi kebakaran.

\section{TUJUAN PENELITIAN}

Penelitian ini bertujuan untuk mengetahui tingkat keandalan sistem keselamatan bangunan dari bahaya kebakaran gedung Rumah Sakit M. Djamil yang termasuk dalam kategori Rumah Sakit Umum Pusat (RSUP) melalui serangkaian pemeriksaan sistem keselamatan bangunan rumah sakit tersebut dengan mengaplikasikan SNI 03-7017.2-2004 tentang pemeriksaan keselamatan kebakaran pada bangunan gedung.

\section{TINJAUAN PUSTAKA}

Bangunan gedung merupakan salah satu wujud fisik pemanfaatan ruang, karena itu dalam pengaturan bangunan gedung tetap mengacu pada pengaturan penataan ruang sesuai peraturan perundang-undangan yang berlaku. Berdasarkan Keputusan Menteri Pekerjaan Umum Tahun 1998, bangunan gedung terbagi atas 10 golonganyakni kelas 1 sampai dengan kelas 10 yang dibagi berdasarkan jenis pemanfaatannya.

\subsection{Tapak Bangunan}

Adapun ketentuan dari tata letak tapak bangunan sebagai berikut :

1. Tinggi rendah pekarangan harus dibuat dengan tetap menjaga keserasian lingkungan serta tidak merugikan pihak lain.

2. Penambahan lantai atau tingkat suatu bangunan gedung diperkenankan apabila masih memenuhi batas ketinggian yang ditetapkan dalam rencana tata ruang kota, harus memenuhi persyaratan teknis yang berlaku dan keserasian lingkungan.

3. Penambahan lantai/ tingkat harus memenuhi persyaratan keamanan struktur.

\subsection{Sarana Penyelamatan}

Akses keluar pada saat terjadi kebakaran merupakan hal yang penting bagi pengguna gedung. Sehingga sarana penyelamatan seperti tangga, ramp kendaraan dan lorong harus aman bagi lalu lintas pengguna bangunan.

Pengertian aman bukan hanya menyangkut aspek konstruksi dimana tangga, ramp, lantai, balkon, dan atap harus mempunyai dinding pembatas/ penghalang, namun dari segi bahannya harus terbuat dari material yang tidak mudah terbakar dan bila terjadi kerusakan setempat tidak merusak struktur yang dapat melemahkan ketahanan saf terhadap api.

\section{6 | JURNAL REKAYASA SIPIL}




\subsection{Sistem Proteksi Pasif}

Sistem proteksi pasif adalah kemampuan stabilitas struktur dan elemennya, konstruksi tahan api, kompartemenisasi dan pemisahan, serta proteksi pada bukaan yang ada untuk menahan dan membatasi kecepatan menjalarnya api dan asap kebakaran. Sistem proteksi pasif terdiri dari :

\subsubsection{Ketahanan Api dan Stabilitas}

Suatu bangunan gedung harus mampu secara struktural stabil selama kebakaran sehingga pada saat terjadi kebakaran pengguna gedung punya cukup waktu untuk evakuasi secara aman. Selain itu juga dapat memberikan cukup waktu bagi pasukan pemadam kebakaran memasuki lokasi untuk memadamkan api.

\subsubsection{Tipe Konstruksi Tahan Api}

Dikaitkan dengan ketahanannya terhadap api, terdapat 3 (tiga) tipe konstruksi yaitu:

a. Tipe A, yaitu konstruksi yang unsur-unsur struktur pembentuknya adalah tahan api.

b. Tipe B, yaitu konstruksi yang unsur-unsur struktur pembentuk kompartemen penahanan api.

c. Tipe C, yaitu Konstruksi yang terbentuk dari unsur-unsur struktur yang dapat terbakar dan tidak dimaksudkan untuk mampu bertahan terhadap api.

\subsubsection{Tipe Konstruksi yang Diwajibkan}

Minimum tipe konstruksi tahan api dari suatu bangunan harus sesuai dengan ketentuan pada Tabel 1 berikut.

\section{Tabel 1. Tipe Konstruksi yang Diwajibkan}

\begin{tabular}{|c|c|c|}
\hline \multirow{2}{*}{$\begin{array}{c}\text { Ketinggian } \\
\text { (dalam jumlah lantai) }\end{array}$} & \multicolumn{2}{|c|}{ Kelas Bangunan } \\
\cline { 2 - 3 } & $\mathbf{2 , 3 , 9}$ & $\mathbf{5 , 6 , 7 , 8}$ \\
\hline 4 atau lebih & $\mathrm{A}$ & $\mathrm{A}$ \\
\hline 3 & $\mathrm{~A}$ & $\mathrm{~B}$ \\
\hline 2 & $\mathrm{~B}$ & $\mathrm{C}$ \\
\hline 1 & $\mathrm{C}$ & $\mathrm{C}$ \\
\hline
\end{tabular}

(Sumber : Badan Litbang PU Departemen Pekerjaan Umum)

\subsubsection{Kompartemenisasi dan Pemisahan}

Kompartemenisasi merupakan suatu usaha untuk mencegah penjalaran kebakaran dengan cara membatasi api dengan dinding, lantai, kolom, balok dan elemen lainnya yang tahan terhadap api dalam waktu yang sesuai dengan kelas bangunan. Ukuran kompartemenisasi dan konstruksi pemisah harus dapat membatasi kobaran api yang potensial, perambatan api dan asap.

\subsubsection{Proteksi Bukaan}

Seluruh bukaan harus dilindungi dan lubang utilitas harus diberi penyetop api untuk mencegah merambatnya api serta menjamin pemisahan dan kompartemenisasi bangunan. Bukaan vertikal pada bangunan yang dipergunakan untuk shaft pipa, shaft ventilasi, dan shaft instalasi listrik harus sepenuhnya tertutup dengan dinding dari bawah sampai atas, dan tertutup pada setiap lantai.

\subsection{Sistem Proteksi Aktif}

Sistem proteksi aktif adalah kemampuan peralatan dalam mendeteksi dan memadamkan kebakaran, pengendalian asap, dan sarana penyelamatan kebakaran.

\subsubsection{Sistem Pemadam Kebakaran}

a. Hidran Kebakaran

Sistem hidran harus dipasang pada bangunan yang memiliki luas lantai total lebih dari $500 \mathrm{~m}^{2}$.

b. Sistem Sprinkler

Sistem sprinkler harus dipasang pada bangunan sebagaimana ditunjukkan pada tabel berikut. 
Tabel 2. Persyaratan Pemakaian Sprinkler

\begin{tabular}{|c|c|}
\hline Jenis Bangunan & Kapan Sprinkler Dipergunakan \\
\hline $\begin{array}{l}\text { Semua Klas Bangunan: } \\
\text { 1. Termasuk lapangan parkir terbuka dalam } \\
\text { bangunan campuran } \\
\text { 2. Tidak termasuk lapangan parkir terbuka } \\
\text { yang merupakan bangunan terpisah }\end{array}$ & Pada bangunan yang tinggi efektifnya lebih dari $25 \mathrm{~m}$ \\
\hline Bangunan Pertokoan (kbs 6) & $\begin{array}{l}\text { Dalam kompartemenisasi dengan salah satu ketentuan } \\
\text { berikut : } \\
\text { (a). Luas lantai lebih dari } 3.500 \mathrm{~m}^{2} \\
\text { (b). Volume ruangan lebih dari } 21.000 \mathrm{~m}^{3}\end{array}$ \\
\hline Bangunan Rumah Sakit & Lebih dari 2 lantai \\
\hline Ruang Pertemuan Umum, & Luas panggung dan belakang panggung \\
\hline Ruang Pertunjukkan, Teater & Lebih dari $200 \mathrm{~m}$ \\
\hline Konstruksi Atrium & Tiap bangunan beratrium \\
\hline Bangunan Berukuran Besar dan Terpisah & $\begin{array}{l}\text { Untuk memperoleh ukuran kompartemen yanglebih besar: } \\
\text { (a). bangunan klas } 5-9 \text { dengan luas maksimum } 18.000 \mathrm{~m}^{2} \\
\text { dan volume } 108.000 \mathrm{~m}^{3} \\
\text { (b). semua bangunan dengan luas lantai lebih besar } \\
\text { dari18.000 } \mathrm{m}^{2} \text { dan volume } 108.000 \mathrm{~m}^{3}\end{array}$ \\
\hline Ruang Parkir, selain Ruang Parkir Terbuka & Bila menampung lebih dari 40 kendaraan \\
\hline $\begin{array}{l}\text { Bangunan dengan Resiko Bahaya Kebakaran } \\
2 \text { persyaratan berikut : } \\
\text { amat tinggi, } * \text { ) }\end{array}$ & $\begin{array}{l}\text { Pada kompartemen, dengan salah satu dari } 2 \text { persyaratan : } \\
\text { (a). Luas lantai melebihi } 2.000 \mathrm{~m}^{2} \\
\text { (b). Volume lebih dari } 12.000 \mathrm{~m}^{3}\end{array}$ \\
\hline
\end{tabular}

(Sumber : Badan Litbang PU Departemen Pekerjaan Umum)

*) Jenis bangunan dengan resiko bahaya kebakaran tinggi sesuai standar teknis yang berlaku.

c. Pemadam Api Ringan (PAR)

PAR yang jenisnya sesuai kebutuhan harus dipasang diseluruh bangunan, kecuali di dalam unit hunian bangunan klas 2 atau klas 3 atau sebagian bangunan klas 4, yang memungkinkan dilakukannya pemadaman awal efektif terhadap kebakaran oleh penghuni bangunan.

\subsubsection{Sistem Deteksi dan Alarm Kebakaran}

Sistem deteksi dan alarm kebakaran otomatis harus dipasang di bangunan kelas $1 \mathrm{~b}$, bangunan klas 2 dengan persyaratan khusus, bangunan klas 3 yang menampung lebih dari 20 penghuni dan dibangunan klas $9 \mathrm{a}$.

\subsubsection{Penqendalian Asap Kebakaran}

Pada saat terjadi kebakaran, setiap rute evakuasi harus dijaga dengan ketinggian asap sekurangkurangnya $2,10 \mathrm{~m}$ di atas level lantai, sehingga temperatur ruang dan tingkat racun asap tidak membahayakan manusia selama tenggang waktu sampai dengan seluruh penghuni dapat terevakuasi dari bangunan. Pengendalian ini juga memungkinkan diketahui rute evakuasi oleh tingkat penglihatan yang ada.

\subsubsection{Pusat Pengendali Kebakaran}

Pusat Pengendali Kebakaran adalah: sebuah ruang untuk pengendalian dan pengarahan selama berlangsungnya operasi penanggulangan kebakaran atau penanganan kondisi darurat lainnya. 


\section{METODOLOGI PENELITIAN}

\subsection{Variabel dalam Sistem Keselamatan Kebakaran Gedung}

Variabel yang diperiksa dalam sistem keselamatan kebakaran terdiri atas empat variabel, yakni :

1. Kelengkapan tapak.

2. Sarana penyelamatan.

3. Sistem proteksi kebakaran pasif.

4. Sistem proteksi aktif.

Sistem proteksi yang diidentifikasi, yaitu berupa kondisi fisik bangunan yaitu lingkungan bangunan dan kelengkapan fisik alat proteksi kebakaran, serta fungsi kerja alat proteksi kebakaran.

\subsection{Instrumen yang Digunakan}

Instrumentasi observasi sistem keselamatan bangunan Rumah Sakit, antara lain :

a. Lembar checklist observasi sarana keselamatan bangunan.

b. Kamera untuk dokumentasi foto.

c. Meteran untuk pengukuran.

\subsection{Metode Pemeriksaan}

Periksa dan catat kondisi nyata sistem proteksi kebakaran yang ada baik di dalam maupun di luar gedung, yang meliputi:

a. Jumlah setiap jenis komponen sistem proteksi kebakaran untuk seluruh gedung.

b. Jumlah setiap jenis komponen sistem proteksi kebakaran pada setiap tingkat.

c. Jumlah setiap jenis komponen sistem proteksi kebakaran yang rusak/tidak berfungsi.

\subsection{Kriteria Penilaian}

Nilai kondisi komponen proteksi kebakaran bangunan dibagi dalam tiga tingkat, yaitu: BAIK = "B", SEDANG atau CUKUP = "C" dan KURANG = "K". Ekuivalensi nilai "B" adalah 100, nilai "C" adalah 80 dan nilai "K" adalah 60 .

Tabel 3. Tingkat Penilaian Audit Kebakaran

\begin{tabular}{|c|l|c|}
\hline Nilai & \multicolumn{1}{|c|}{ Kesesuaian } & Keandalan \\
\hline$>80-100$ & Sesuai persyaratan & $\mathrm{B}=$ Baik \\
\hline $60-80$ & $\begin{array}{l}\text { Terpasang tapi ada sebagian kecil instalasi yang tidak } \\
\text { sesuai persyaratan }\end{array}$ & $\mathrm{C}=$ Cukup \\
\hline$<60$ & Tidak sesuai sama sekali & $\mathrm{K}=$ Kurang \\
\hline
\end{tabular}

(Sumber : Badan Litbang PU Departemen Pekerjaan Umum)

Pembobotan memakai standar yang telah ada, yaitu penentuan pembobotan dengan metode Analitycal Hierarchycal Process (AHP).

\section{Tabel 4. Pembobotan Parameter Komponen}

\begin{tabular}{|c|l|c|}
\hline No. & \multicolumn{1}{|c|}{ Parameter KSKB } & Bobot KSKB \\
\hline 1. & Kelengkapan Tapak & $25 \%$ \\
\hline 2. & Sarana Penyelamatan & $25 \%$ \\
\hline 3. & Sistem Proteksi Aktif & $24 \%$ \\
\hline 4. & Sistem Proteksi Pasif & $26 \%$ \\
\hline
\end{tabular}

(Sumber : Badan Litbang PU Departemen Pekerjaan Umum) 


\subsection{Klasifikasi Tingkat Keandalan Keselamatan Bangunan}

a. Baik, bila nilai NKSKB tidak kurang antara $80 \%-100 \%$.

b. Cukup baik, bila $60 \%<$ NKSKB $<80 \%$

c. Kurang, bila NKSKB $<60 \%$

\section{HASIL DAN PEMBAHASAN}

Berdasarkan hasil pengolahan data pada bab sebelumnya dapat dilihat nilai keandalan sistem keselamatan bangunan (NKSKB) pada setiap bangunan gedung di komplek RSUP DR. M. Djamil Padang. Adapun rekapitulasi hasil penilaian NKSKB pada setiap gedung dapat dilihat pada Lampiran Tabel 1.

Dari data di atas dapat diketahui bahwa Nilai Keandalan Sistem Keselamatan Bangunan (NKSKB) sebagian besar adalah bernilai "baik" dan hanya sebagian kecil bangunan yang bernilai "cukup". Adapun persentase terhadap perbandingan NKSKB untuk semua bangunan gedung pada komplek RSUP DR. M. Djamil Padang sebagai berikut :

\section{Tabel 5. Persentase Perbandingan NKSKB}

\begin{tabular}{|c|l|c|}
\hline No. & \multicolumn{1}{|c|}{ Kriteria } & Persentase (\%) \\
\hline 1 & Baik & 92.59 \\
\hline 2 & Cukup & 7.41 \\
\hline 3 & Kurang & 0.00 \\
\hline
\end{tabular}

\subsection{Evaluasi Kelengkapan Tapak RSUP.DR. M. Djamil Padang}

1. Sumber Air

Kapasitas air yang ada sudah mencukupi terhadap fungsi bangunan. Air yang tersedia ditempatkan pada suatu lokasi penampungan seperti yang terlihat pada Gambar 1.

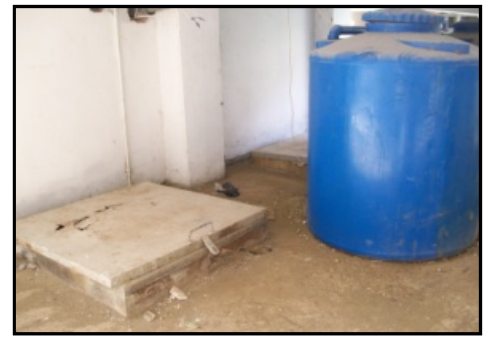

Gambar 1. Sumber Air

2. Jalan Lingkungan

Lebar jalan lingkungan sudah mencukupi syarat yang ditentukan yaitu minimal $6 \mathrm{~m}$. Selain itu juga diberi pengerasan aspal. Namun jalur kendaraan yang ada tidak sepenuhnya mengelilingi bangunan yang ada di kompleks rumah sakit tersebut.

3. Jarak Antar Bangunan

Jarak antar bangunan pada setiap gedung telah sesuai dengan persyaratan yang ada yaitu gedung dengan ketinggian sampai $8 \mathrm{~m}$ berjarak minimal $3 \mathrm{~m}$. Gedung dengan ketinggian $8-14 \mathrm{~m}$ berjarak minimal $6 \mathrm{~m}$, sedangkan gedung dengan ketinggian $40 \mathrm{~m}$ ke atas memiliki jarak minimal $8 \mathrm{~m}$. Hal tersebut dapat dilihat pada Gambar 2.

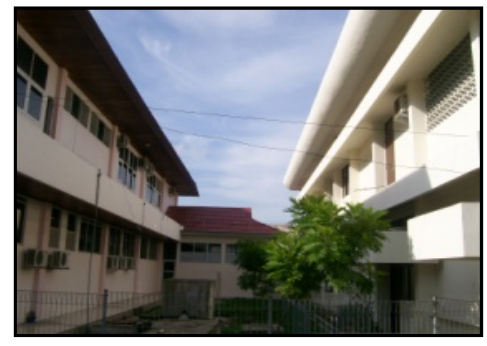

Gambar 2. Jarak antar Bangunan 
4. Hidran Halaman

Hidran halaman terdapat pada tempat yang mudah dijangkau tetapi tidak berfungsi secara sempurna dikarenakan peralatan yang kurang terawat dan jarang sekali dilakukan uji coba alat.

\subsection{Evaluasi Sarana Penyelamatan Gedung RSUP DR. M. Djamil Padang}

1. Jalan Keluar Jarak dari dalam bangunan ke luar yang relatif pendek dan tidak membutuhkan waktu yang lama untuk penghuni keluar ruangan. Biasanya akses keluar bagi penghuni gedung yaitu melalui pintu-pintu utama yang langsung menuju keluar ruangan.

2. Konstruksi Jalan Keluar

Rata-rata bentuk konstruksi jalan keluar pada setiap gedung berupa koridor-koridor panjang yang biasa dilalui oleh pasien dan pengunjung rumah sakit. Koridor tersebut terbuat dari beton bertulang yang mampu bertahan terhadap api dalam waktu beberapa jam. Sehingga dapat memberikan waktu evakuasi bagi penghuni bangunan saat terjadi kebakaran.

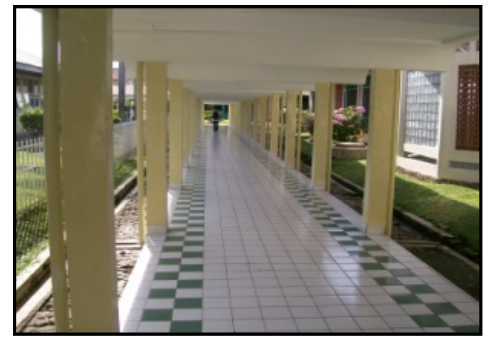

Gambar 3. Konstruksi Jalan Keluar

\subsection{Evaluasi Sistem Proteksi Aktif Gedung RS. M Jamil Padang}

a. Deteksi dan Alarm

Deteksi dan alarm sudah terpasang secara manual pada gedung sesuai SNI 03-3985-2000 yaitu untuk bangunan rumah sakit dengan jumlah lantai 1-4. Tapi di beberapa tempat masih terdapat kerusakan yang diakibatkan kurangnya perawatan alat oleh pihak rumah sakit. Deteksi dan alarm ini juga belum bisa dipastikan bekerja secara sempurna, karena sudah lama belum dilakukan uji coba alat.

b. Siamese Conection

Merupakan sebuah sambungan selang mobil pemadam kebakaran dalam menyuplai air dari sumbernya sewaktu datang ke lokasi terjadinya kebakaran. Alat ini biasanya ditempatkan pada lokasi yang mudah dijangkau mobil pemadam kebakaran. Kondisi alat sekarang belum bisa dipastikan bekerja secara sempurna karena sudah lama tidak digunakan baik untuk saat kebakaran terjadi maupun saat uji coba dilakukan.

c. Pemadam Api Ringan (PAR)

Alat ini merupakan sistem pemadam api portabel yang dapat digunakan langsung saat terjadi kebakaran. Biasanya digunakan dalam memadamkan kebakarankebakaran kecil. Jarak perletakan alat juga telah sesuai standar yaitu maksimal $25 \mathrm{~m}$.

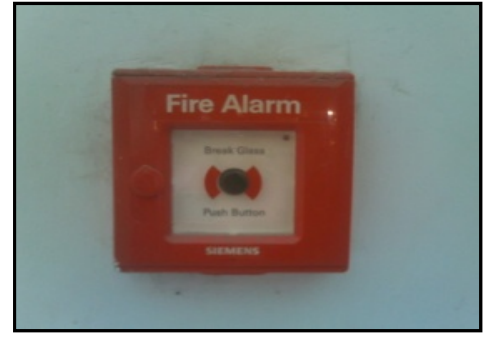

Gambar 4. Alarm Kebakaran

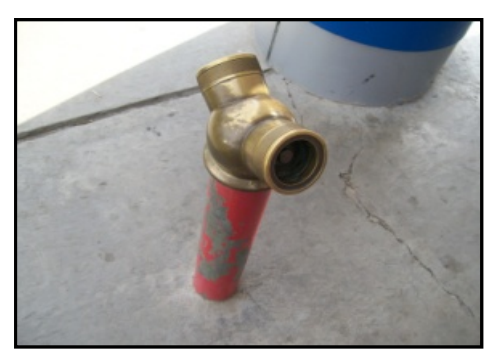

Gambar 5. Siamese Conection



Gambar 6. Alat Pemadam Api Ringan 
d. Hidran Gedung

Hidran yang terdapat di dalam gedung telah sesuai standar tata cara pemasangan hidran (SNI 03-17451989). Namun pada gedung RRI Penyakit Dalam terdapat box hydrant yang masih kosong yang belum terisi selang air. Sedangkan untuk gedung lainnya terdapat box hydrant yang lengkap dengan isinya, tetapi kondisinya kurang terpelihara karena jarang digunakan.

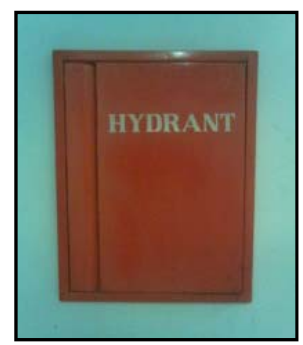

Gambar 7. Hidran Gedung

e. Sprinkler

Alat ini sama sekali tidak terdapat pada setiap gedung di RS M. Djamil Padang, walaupun dalam peraturannya untuk bangunan klas 9a (bangunan perawatan kesehatan) yang memiliki lantai lebih dari 2 harus dipasang sistem sprinkler (Kep.Men.PU No. 441/KPTS/1998 tentang persyaratan teknis bangunan gedung). Sehingga dalam melakukan pemeriksaan diberikan penilaian sama dengan nol.

f. Sistem Pemadam Luapan

Sistem tersebut berlaku untuk ruangan/ bangunan yang memerlukan sistem khusus seperti ruang komunikasi, ruang komputer, ruang magnetik, ruang elektronik, dan lainnya. Sistem pemadam khusus dapat berupa gas, busa dan bubuk kering. Alat ini tidak tersedia pada gedung rumah sakit karena dirasa tidak perlu disediakan pada gedung perawatan kesehatan.

g. Pengendali Asap

Pengendali asap merupakan suatu alat yang berguna untuk mengendalikan asap yang terdapat di dalam ruangan pada saat kebakaran terjadi untuk selanjutnya dibuang keluar bangunan. Hal ini mengingat bahwa asap tersebut dapat membahayakan jiwa orang yang berada di dalam gedung. Alat ini berupa kipas/fan yang berputar setelah aktifnya detektor asap yang ditempatkan dalam zona yang sesuai dengan reservoir asap yang dilayani fan. Alat ini tidak dapat dijumpai pada setiap gedung dalam komplek rumah sakit.

h. Deteksi Asap (Smoke Detector)

Berdasarkan survei, tata cara pemasangan deteksi asap pada gedung yang ditinjau telah memenuhi standar yang berlaku (SNI 03-3689), yaitu jarak antar detektor $<20 \mathrm{~m}$ dan jarak dari detektor ke dinding $<10 \mathrm{~m}$. Namun detektor asap tidak dapat mengoperasikan sistem pengolahan udara secara otomatis melainkan hanya dapat memberikan peringatan bagi penghuni gedung saat terjadi kebakaran.



Gambar 8. Smoke Detector

i. Pembuangan Asap

Pembuangan asap merupakan suatu alat yang berguna untuk mengeluarkan asap dari dalam ruangan menuju keluar gedung pada saat kebakaran terjadi. Dalam peraturannya setiap reservoir asap dilayani minimal satu buah fan yang mampu menghisap asap. Selain itu fan tersebut terletak didalam reservoir asap dengan ketinggian $2 \mathrm{~m}$ dari lantai. Alat ini juga tidak tersedia pada setiap gedung dalam kompleks rumah sakit.

j. Lift Kebakaran

Perencanaan dan pemasangan lift pada gedung yang ditinjau telah sesuai dengan peraturan yang ada, yaitu lift ditempatkan pada lokasi yang mudah dijangkau oleh pemakai, lift ditempatkan dalam saft yang tahan api, listrik berasal dari 2 sumber dengan menggunakan kabel tahan api, dan memiliki akses kesetiap lantai. Berdasarkan gedung yang di survei, tidak 
terdapat lift yang khusus digunakan saat kebakaran terjadi melainkan lift yang biasa digunakan pengguna untuk transportasi dalam gedung. Namun lift tersebut dapat dikondisikan sebagai lift kebakaran.

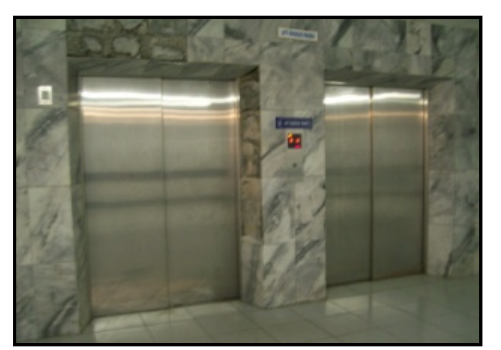

Gambar 9. Lift Kebakaran

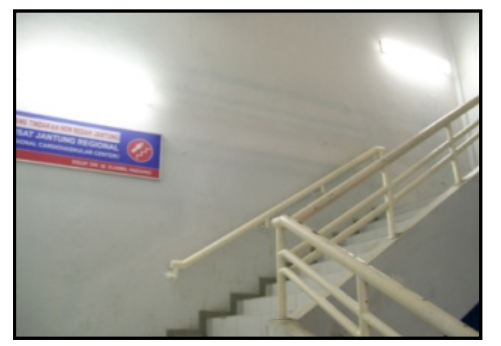

Gambar 10. Pencahayaan Darurat

1. Petunjuk Arah

Petunjuk arah juga dinilai baik karena tanda arah menuju keluar ruangan dipasang dengan tulisan yang jelas dan ditempatkan di lokasi yang mudah terlihat oleh pengguna gedung. Sedangkan jarak antar tanda arah tersebut dipasang tidak berjauhan sehingga tidak membingungkan pengguna gedung saat terjadi kondisi darurat.

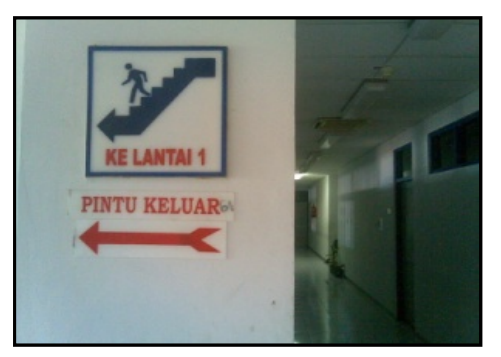

Gambar 11. Tanda Arah

m. Listrik Darurat

Daya yang disuplai pada gedung rumah sakit ini berasal dari 2 sumber yaitu daya listrik PLN dan sumber daya darurat berupa generator. Pemasangan instalasi listrik pada bangunan ini juga telah sesuai dengan peraturan umum instalasi listrik tegangan rendah (SNI 04-02252000).

n. Ruang Pengendali Operasi

Pada survey gedung yang ditinjau, di rumah sakit ini terdapat 1 buah ruangan pengendali operasi yang dapat memonitor bangunan seperti IGD, CSSD, Instalasi Laboratorium, dan Instalasi Bedah Central (IBC). Ruangan tersebut telah direncanakan dapat memonitor kebakaran yang terjadi dengan menggunakan peralatan yang lengkap. Namun kondisi ruangan tersebut kurang terjaga disebabkan jarangnya dilakukan pemeriksaan pada ruangan tersebut.

\subsection{Evaluasi Sistem Proteksi Pasif Gedung RSUP DR M. Djamil Padang}

a. Ketahanan Api pada Struktur bangunan

Bangunan gedung rumah sakit yang ditinjau memiliki struktur yang mampu bertahan terhadap penjalaran api yaitu berupa beton bertulang, sehingga memberikan waktu bagi penghuni gedung untuk melakukan evakuasi secara aman. Selain itu juga dapat memberikan waktu bagi petugas pemadam kebakaran untuk memadamkan api sehingga mengurangi kerusakan terhadap properti lainnya. 
b. Kompartemenisasi Ruang

Ukuran kompartemenisasi dan konstruksi pemisah harus dapat membatasi kobaran api yang terjadi, sehingga dapat memberikan perlindungan bagi penghuni yang berada diruangan lain di dalam bangunan. Selain itu juga membatasi penjalaran api dan memudahkan bagi petugas pemadam kebakaran dalam melaksanakan tugasnya.

c. Perlindungan Bukaan

Bukaan yang terdapat pada gedung yang ditinjau rata-rata telah diproteksi terhadap penjalaran api. Sedangkan bukaan vertikal diberikan penyetop api dari bawah sampai lantai atas dan disetiap lantai diberikan penutup tahan api. Namun sarana proteksi pada bukaan masih kurang tersedia seperti pintu dan jendela kebakaran, pintu penahan asap dan panahan api.

\section{KESIMPULAN}

Kesimpulan yang dapat diperoleh dari hasil penelitian ini adalah :

1. Evaluasi NKSKB terhadap semua gedung Rumah Sakit M. Jamil Padang memiliki Nilai Keandalan Sistem Keselamatan Bangunan (NKSKB) > 80 yaitu 82,17 dengan kondisi fisik komponen keselamatan kebakaran yang dinilai baik berdasarkan standar jumlah, ukuran, kelengkapan alat, maupun dari fungsi alat pada komponen kelengkapan tapak, sarana penyelamatan, proteksi aktif dan proteksi pasif bangunan. Dengan demikian 27 gedung obyek penelitian dapat digunakan secara optimal dan pengguna bangunan mendapat perlindungan yang baik dari bahaya kebakaran bangunan.

2. Jika ditinjau dari persentase NKSKB pada setiap gedung rumah sakit, sekitar $92,59 \%$ gedung yang memiliki tingkat keandalan "BAIK" sedangkan gedung sisanya mempunyai tingkat keandalan "cukup" dengan persentase sekitar 7,41 \%. Pada pemeriksaan sistem keselamatan kebakaran ini tidak terdapat gedung yang memiliki tingkat keandalan "KURANG".

3. Dari komponen pembentuk NKSKB, maka disimpulkan komponen proteksi aktif merupakan komponen yang mempunyai nilai paling rendah yakni 13,4 dari skala 24,34. Hal itu dikarenakan karena tidak ada satu pun gedung yang ada di Rumah Sakit M. Djamil yang mempunyai kelengkapan fasilitas system proteksi aktif kebakaran. Ada 2 elemen yang tidak terdapat yakni sprinkler dan lift kebakaran sedangkan hidran serta deteksi dan alarm tidak berada dalam kondisi yang baik. Hasil tersebut cukup mengejutkan mengingat kebanyakan gedung-gedung lebih banyak bertumpu kepada sistem proteksi aktif dalam penanganan sistem keselamatan bangunannya.

4. Berdasarkan tingkat resiko kebakaran, gedung IPAL \& incinerator memiliki tingkat keandalan cukup mempunyai tingkat resiko kebakaran yang tinggi sehingga manajemen rumah sakit perlu memperhatikan secara khusus gedung tersebut. Sedangkan gedung instalasi pemeliharaan sarana yang juga memiliki nilai keandalan cukup mempunyai tingkat resiko kebakaran yang rendah.

5. "Tool" yang dipakai dirasa kurang efektif terhadap bangunan sederhana yaitu bangunan dengan dimensi yang relatif kecil dan hanya memiliki satu buah lantai. Ini disebabkan adanya komponen pemeriksaan yang dirasa tidak cocok untuk kondisi bangunan yang ditinjau seperti aturan mengenai landasan helikopter.

\section{DAFTAR PUSTAKA}

Arie's Site, (2008), Tidak Ada Satupun Gedung yang Tahan Kebakaran. (online: http://www. arialat.multiply.com/journal/item/6 - 30k, akses 12 Maret 2008). 
Endangsih, Tri, (2008), Pengaruh Material Terhadap Bahaya Kebakaran Ditinjau dari Desain Bangunan dan Waktu Evakuasi. (online: http://www.peneliti. bl.ac.id/wp-content/ uploads/2007/05/endang-sna2007.pdf akses 13 Maret 2008).

Keputusan Menteri Negara Pekerjaan Umum Nomor: 10/kpts/2000, tentang Ketentuan Teknis Pengamanan Terhadap Bahaya Kebakaran pada Bangunan Gedung dan Lingkungan.

Keputusan Menteri Pekerjaan Umum Nomor : 441/KPTS/1998, tentang Persyaratan Teknis Bangunan Gedung.

Prihatmaji, P.Y., "Building Standard \& Role for Building Safety-Security".

SNI 03-1735-2000, Tata Cara Perencanaan Akses Bangunan dan Akses Lingkungan untuk Pencegahan Bahaya Kebakaran pada Bangunan Rumah dan Gedung.

SNI 03-1745-1989, Pemasangan Sistem Hidran untuk Pencegahan Bahaya Kebakaran pada Bangunan Rumah dan Gedung.

SNI 03-3985-2000, Tata Cara Perencanaan, Pemasangan dan Pengujian Sistem Deteksi dan Alarm Kebakaran untuk Pencegahan Bahaya Kebakaran oada Bangunan Gedung.

SNI 03-1735-2000, Tata Cara Perencanaan Akses Bangunan dan Akses Lingkungan untuk Pencegahan Bahaya Kebakaran pada Bangunan Gedung.

SNI 1728-1989, Pemeriksaan Keselamatan Kebakaran Bangunan Gedung. (online: http://www.pu.go.id/ditjen_mukim / abstraksi / index. asp? action = menu bg\&inc=kesehatan $\underline{40 \mathrm{k}}$ akses 13 Maret 2008).

\section{LAMPIRAN}

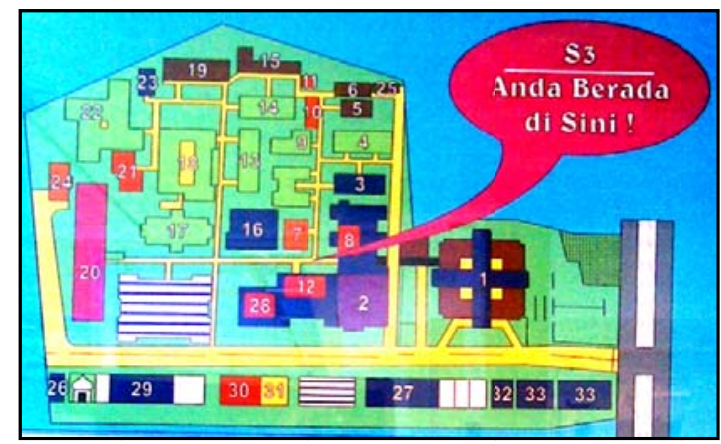

Gambar 1. Denah RSUP DR. M. Djamil Padang

Keterangan :

1. URJ (Unit Rawat Jalan)

2. IGD (Instalasi Gawat Darurat)

3. Inst. Rehab. dan RRI Kulit \& Kelamin

4. RRI Syaraf

5. Instalasi Pemulasaran Jenazah

6. Instalasi Pemeliharaan Sarana

7. Instalasi Radiologi

8. Instalasi Laboratorium

9. RRI Paru

10. Boiler

11. Genset

12. IBC (Instalasi Bedah Central)

13. RI Mata

14. RRI THT
15. Instalasi Binatu \& Laundry

16. Trauma Center

17. RRI Penyakit Dalam

18. RRI Bedah

19. Instalasi Gizi

20. RRI Kelas I/Utama

21. RRI Petri/Isolasi

22. RRI Anak

23. Kantor UPF Penyakit Anak

24. Instalasi Radiologi

25. IPAL \& Incenerator

26. CSSD

27. Pusat Jantung Regional 
Tabel 1.

Rekapitulasi Data Nilai NKSKB Gedung RS. X

\begin{tabular}{|c|c|c|c|c|c|c|c|}
\hline \multirow{2}{*}{ No. } & \multirow{2}{*}{ Nama Bangunan } & \multicolumn{4}{|c|}{ KSKB } & \multirow{2}{*}{ NKSKB } & \multirow{2}{*}{ Keterangan } \\
\hline & & A & B & C & D & & \\
\hline 1. & CSSD & 23,75 & 23,10 & 18,91 & 24,34 & 90,10 & Baik \\
\hline 2. & Inst. Bedah Central (IBC) & 23,75 & 23,10 & 18,43 & 24,34 & 89,62 & Baik \\
\hline 3. & Instalasi Gawat Darurat (IGD) & 23,75 & 23,10 & 18,14 & 24,34 & 82,58 & Baik \\
\hline 4. & Inst. Laboratorium & 23,75 & 23,10 & 18,05 & 24,34 & 89,23 & Baik \\
\hline 5. & RRI Penyakit Dalam & 22,50 & 23,10 & 16,22 & 24,34 & 86,16 & Baik \\
\hline 6. & Inst. Radiologi & 23,75 & 23,10 & 12,24 & 24,34 & 83,43 & Baik \\
\hline 7. & Inst. Rehab.\& RRI kulit \& kelamin & 22,50 & 23,10 & 13,25 & 24,34 & 76,43 & Baik \\
\hline 8. & Kantor UPF Penyakit Anak & 22,50 & 23,10 & 13,25 & 24,34 & 83,18 & Baik \\
\hline 9. & RRI Kelas I / Utama & 22,50 & 23,10 & 13,25 & 24,34 & 83,18 & Baik \\
\hline 10. & Inst. Pemulasaran Jenazah & 22,50 & 23,10 & 12,24 & 24,34 & 82,18 & Baik \\
\hline 11. & Inst. Radiologi & 22,50 & 23,10 & 12,24 & 24,34 & 82,18 & Baik \\
\hline 12. & Pusat jantung Regional & 22,50 & 23,10 & 12,24 & 24,34 & 82,18 & Baik \\
\hline 13. & RRI Anak & 22,50 & 23,10 & 12,24 & 24,34 & 82,18 & Baik \\
\hline 14. & RRI Mata & 22,50 & 23,10 & 12,24 & 24,34 & 82,18 & Baik \\
\hline 15. & RRI Syaraf & 22,50 & 23,10 & 12,24 & 24,34 & 82,18 & Baik \\
\hline 16. & RRI THT & 22,50 & 23,10 & 12,24 & 24,34 & 82,18 & Baik \\
\hline 17. & Unit Rawat Jalan (URJ) & 22,50 & 23,10 & 11,86 & 24,34 & 75,05 & Baik \\
\hline 18. & Boiler & 21,35 & 23,10 & 12,24 & 24,34 & 81,03 & Baik \\
\hline 19. & Genset & 21,35 & 23,10 & 12,24 & 24,34 & 81,03 & Baik \\
\hline 20. & Inst. Binatu \& Laundry & 21,35 & 23,10 & 12,24 & 24,34 & 81,03 & Baik \\
\hline 21. & Inst. Gizi & 21,35 & 23,10 & 12,24 & 24,34 & 81,03 & Baik \\
\hline 22. & RRI Bedah & 21,35 & 23,10 & 12,24 & 24,34 & 81,03 & Baik \\
\hline 23. & RRI Paru & 21,35 & 23,10 & 12,24 & 24,34 & 81,03 & Baik \\
\hline 24. & RRI Petri / Isolasi & 21,35 & 23,10 & 12,24 & 24,34 & 81,03 & Baik \\
\hline 25. & Trauma Centre & 21,35 & 23,10 & 12,24 & 24,34 & 81,03 & Baik \\
\hline 26. & Inst. Pemeliharaan Sarana & 20,10 & 21,35 & 12,24 & 24,34 & 78,03 & Cukup \\
\hline \multirow[t]{2}{*}{27.} & IPAL \& Incenerator & 20,10 & 21,35 & 12,24 & 24,34 & 78,03 & Cukup \\
\hline & Rata-Rata & 22,21 & 22,97 & 13,40 & 24,34 & 82,17 & Baik \\
\hline
\end{tabular}

Keterangan :



